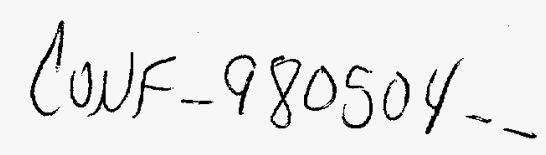

\title{
THE EFFECTS OF BERYLLIUM ADDITIONS ON THE OXIDATION OF NICKEL ALUMINIDE AND TITANIUM ALUMINIDE BASED INTERMETALLICS
}

\author{
Robert J. Hanrahan Jr., Katherine C. Chen \\ Los Alamos National Laboratory \\ Materials Science and Technology Division \\ M.S. G770 \\ Los Alamos, NM 87545-1663 \\ and \\ Michael P. Brady \\ Metals and Ceramics Division \\ Oak Ridge National Laboratory \\ M.S. 6115 \\ Oak Ridge, TN 37831-6115
}

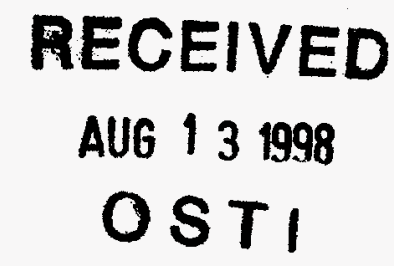

ABSTRACT

The effects of $\mathrm{Be}$ additions on the oxidation behavior of $\beta-\mathrm{NiAl}$ in moist air at $1000^{\circ} \mathrm{C}$ as well as on the borderline alumina-forming $\gamma+$ Laves Ti-Al-Cr based alloys at $800^{\circ} \mathrm{C}$ and $1000^{\circ} \mathrm{C}$ in dry and moist air were investigated. The addition of Be to $\beta-\mathrm{NiAl}$ suppressed the formation of transient alumina and resulted in the formation of a protective $\mathrm{BeAl}_{2} \mathrm{O}_{4}$ spinel phase. In dry air, the addition of $\mathrm{Be}$ to the Ti-Al-Cr alloys also resulted in the formation of a protective $\mathrm{BeAl}_{2} \mathrm{O}_{4}$ spinel phase. In moist air, only Ti-Al$\mathrm{Cr}-\mathrm{Be}$ alloys with a high $\mathrm{Cr}$ content $\left(10\right.$ to $15 \mathrm{a} / \mathrm{o}$ ) formed the protective $\mathrm{BeAl}_{2} \mathrm{O}_{4}$ scale.

\section{INTRODUCTION}

Beryllium is attractive as an alloying addition to improve the performance of intermetallics because of its low density and the protective nature of its oxide. Unfortunately, due to the health hazards of handling beryllium and its compounds, very little research on the oxidation of Be alloys has been reported to date. We have conducted some selected studies to determine the potential of minor Be additions to improve the mechanical and oxidative properties of intermetallics. In this paper, we report the results of our study of the effects of $\mathrm{Be}$ on the oxidation resistance of alloys based on the Ni-Al and Ti-Al-Cr systems.

The high temperature oxidation of binary $\mathrm{NiAl}$ has been the subject of numerous studies, both because of its use as a coating and its potential application as a structural material. (e.g. references 1-4) The use of $\mathrm{NiAl}$ as a monolithic material is severely restricted by its lack of low temperature ductility and poor high temperature creep resistance $(5,6)$. One of the routes for improving properties at all temperatures is alloying with ternary elements which may substitute for $\mathrm{Al}$, i.e. elements which form $\mathrm{B} 2$ 


\section{DISCLAIMER}

This report was prepared as an account of work sponsored by an agency of the United States Government. Neither the United States Government nor any agency thereof, nor any of their employees, makes any warranty, express or implied, or assumes any legal liability or responsibility for the accuracy, completeness, or usefulness of any information, apparatus, product, or process disclosed, or represents that its use would not infringe privately owned rights. Reference herein to any specific commercial product, process, or service by trade name, trademark, manufacturer, or otherwise does not necessarily constitute or imply its endorsement, recommendation, or favoring by the United States Government or any agency thereof. The views and opinions of authors expressed herein do not necessarily state or reflect those of the United States Government or any agency thereof. 


\section{DISCLAIMER}

Portions of this document may be illegible in electronic image products. Images are produced from the best available original document. 
compounds with $\mathrm{Ni}$ (7). Most of these have been thoroughly investigated with the notable exception of $\mathrm{Be}$, which has only been added at very low levels $(8,9)$. NiBe has been reported to exhibit oxidation kinetics comparable to pure $\mathrm{NiAl}$ when exposed in dry oxygen (10). We have determined that there is significant apparent solubility of $\mathrm{Be}$ in NiAl. (10). The isothermal oxidation kinetics of alloys containing $0,1,3,5$, and $10 \%$ beryllium exposed in dry oxygen have been previously reported (11). In the present work, we have investigated the effects of moisture on the oxidation resistance of these alloys, since water vapor is known to accelerate the oxidation of $\mathrm{Be}(12)$.

Two-phase $\mathrm{TiAl}(\gamma)+\mathrm{Ti}(\mathrm{Cr}, \mathrm{Al})_{2}$ (Laves) alloys are under consideration as oxidation-resistant coatings for the $\gamma$ class of titanium aluminides due to their ability to form a continuous, protective alumina scale (14-16). They also hold promise as a potential oxidation-resistant structural alloy but they are limited by poor room temperature fracture toughness. Reduction in the $\mathrm{Al}$ and $\mathrm{Cr}$ content may result in improved room temperature toughness but would certainly be accompanied by loss of the ability to form a protective alumina scale. To restore the ability of a low $\mathrm{Al} / \mathrm{Cr} \gamma+$ Laves alloy to form alumina, further alloying additions are needed. Be is a possible choice because it forms a $\mathrm{TiBe}_{2}$ Laves phase, which may behave in a similar manner to the $\mathrm{TiCr}_{2}$ Laves phase with regards to high $\mathrm{Al}$ solubility and excellent oxidation resistance $(17,18)$.

\section{EXPERIMENTAL}

$\mathrm{Ni}-\mathrm{Al}-\mathrm{Be}$ alloys based on $\mathrm{Ni}-50 \mathrm{Al}(\mathrm{\beta}-\mathrm{NiAl})$ containing $0,1,2,5,7.5$, and 10 atomic percent $(\mathrm{a} / \mathrm{o}) \mathrm{Be}$ substituted for $\mathrm{Al}$ were selected for study. X-ray diffraction indicated that alloys with up to $7.5 \mathrm{a} / \mathrm{o} \mathrm{Be}$ were single-phase $\beta-\mathrm{NiAl}$ with $\mathrm{Be}$ in solution. The $\mathrm{Ni}-40 \mathrm{Al}-10 \mathrm{Be}$ alloy was primarily $\beta-\mathrm{NiAl}$ with a minor volume fraction of $\mathrm{NiBe}$.

The ternary $\mathrm{Ti}-\mathrm{Al}-\mathrm{Cr}$ alumina-formation boundary defined by Perkins and Meier (14) was used to guide selection of the Ti-Al-Cr-Be alloys (Fig. 1). (Note that the compositions plotted in Fig. 1 are based only on the $\mathrm{Al}$ and $\mathrm{Cr}$ contents in order to highlight their locations relative to the ternary $\mathrm{Ti}-\mathrm{Al}-\mathrm{Cr}$ alumina formation boundary). The compositions selected for study were Ti-50Al-12.5Be, Ti-45Al-7.5Cr-7.5Be, Ti$45 \mathrm{Al}-15 \mathrm{Cr}-\mathrm{Be}$, and $\mathrm{Ti}-47.5 \mathrm{Al}-10 \mathrm{Cr}-5 \mathrm{Be}$. The Ti-50Al-12.5Be alloy was selected to determine if there was a $\gamma+\mathrm{Ti}(\mathrm{Cr}, \mathrm{Be}, \mathrm{Al})_{2}$ analogue to the alumina-forming $\gamma+$ Laves $\mathrm{Ti}-\mathrm{Al}-\mathrm{Cr}$ alloys. The remaining three alloys fall at or below the alumina-formation boundary based on the ternary $\mathrm{Ti}, \mathrm{Al}, \mathrm{Cr}$ contents alone (Fig. 1).

The alloys were prepared by arc-melting and casting high-purity elemental material. After a homogenization anneal at $1200^{\circ} \mathrm{C}$ for 168 hours, specimens were cut from the ingot and the surfaces were prepared by grinding to a 600 grit finish. The homogenization anneal was effective for the Ni-Al based alloys but resulted in an extremely coarse ( $1 \mathrm{~mm}$ and greater grain size) microstructure in the Ti-Al based alloys. 
Samples were placed into a tube furnace and given an isothermal exposure at peak temperatures of 800 and $1000^{\circ} \mathrm{C}$ for 100 hours in dry air or air saturated with moisture by bubbling through a water column at $20^{\circ} \mathrm{C}$. Oxidized samples were characterized by $\mathrm{x}$-ray diffraction (XRD), optical microscopy, and scanning electron microscopy (SEM) equipped with energy dispersive spectroscopy (EDS) mapping. Flat slabs of the oxidized NiAlBe and TiAlCrBe samples were used for phase determinations XRD. A Scintag $\mathrm{XDS} 2000$ diffractometer with a $\mathrm{Cu} \mathrm{K \alpha}$ source was used at $45 \mathrm{kV}$ and $40 \mathrm{~mA}$. Continuous scans of two-theta from $20^{\circ}$ to $100^{\circ}$, with a step size of $0.02^{\circ}$, were acquired at a rate of $0.6 \%$ minute. Peaks were identified with the aid of JCPDS cards, XRD modeling (CaRIne software), references, and phase diagrams

\section{RESULTS AND DISCUSSION}

\section{Ni-Al Based Alloys}

The substitution of $\mathrm{Be}$ for $\mathrm{Al}$ in $\mathrm{NiAl}$ was previously shown to suppress the formation of transient (non $\alpha$ ) aluminas through the formation of a protective $\mathrm{BeO}^{*} \mathrm{Al}_{2} \mathrm{O}_{3}$ $\left(\mathrm{BeAl}_{2} \mathrm{O}_{4}\right)$ spinel phase during short term $(16 \mathrm{~h})$ isothermal exposures from $800-1200^{\circ} \mathrm{C}$ in dry oxygen (11). In the present study, the oxidation behavior of the Be modified NiAl alloys was investigated for $100 \mathrm{~h}$ at $1000^{\circ} \mathrm{C}$ in moist air. Although water vapor is known to accelerate the oxidation of $\mathrm{Be}(12)$, no adverse effects of water vapor on the oxidation of the Ni-Al-Be alloys were observed.

After exposure for $100 \mathrm{~h}$ at $1000^{\circ} \mathrm{C}$ in moist air, the binary $\beta-\mathrm{NiAl}$ alloy exhibited the characteristic granular surface structure typical of the oxidation of $\beta$-NiAl in this temperature range (Fig. 2). This granular surface structure is associated with the formation of transient alumina during the initial transient stages of oxidation(7). In contrast, the $\mathrm{Be}$ modified $\mathrm{NiAl}$ alloys exhibited a planar, nearly transparent surface oxide in which the underlying substrate grain structure was clearly visible (Fig. 2). This morphology is similar to that formed in dry oxygen (11). Therefore, the addition of only 1 $\mathrm{a} / \mathrm{o} \mathrm{Be}$ (the lowest level studied) appears to successfully suppress transient alumina formation at $1000^{\circ} \mathrm{C}$ in both dry oxygen and moist air.

Results from x-ray diffraction of the oxidized alloys are summarized in Table I. Peaks corresponding to $\beta$-NiAl were observed on all of the $\mathrm{NiAl}+\mathrm{Be}$ samples. The $\mathrm{NiAl}$ was noticeably textured with preferred orientations in the (110) and (112) planes. Interestingly, upon oxidation, the $\mathrm{NiAl}(002)$ peaks were severely reduced to nondetectable intensities.

The binary NiAl sample oxidized to form $\alpha-\mathrm{Al}_{2} \mathrm{O}_{3}$ after $100 \mathrm{~h}$ at $1000^{\circ} \mathrm{C}$ in moist air. The addition of only $1 \mathrm{a} / \mathrm{o} \mathrm{Be}$ resulted in the formation of the $\mathrm{BeAl}_{2} \mathrm{O}_{4}$ spinel rather than the $\alpha-\mathrm{Al}_{2} \mathrm{O}_{3}$. The spinel was found to form on the alloys containing up to $7.5 \mathrm{a} / \mathrm{o} \mathrm{Be}$, 
but was not detected in the $10 \mathrm{a} / \mathrm{o}$ Be sample. On the $10 \mathrm{a} / \mathrm{o}$ Be alloy, an unidentified oxide phase (designated $\mathrm{X}$ ) was observed. The $\mathrm{X}$ phase may be $3 \mathrm{BeO}^{*} \mathrm{Al}_{2} \mathrm{O}_{3}$ based on the pattern published by Galakhov (13), although the match is poor and the major peaks were shifted by as much as $1^{\circ}$. The $\mathrm{X}$ phase was also observed on the 5 and $7.5 \mathrm{Be}$ alloys.

Table I: Phases identified by XRD in Ni(Al, Be) alloys after exposure for $100 \mathrm{~h}$ at $1000^{\circ} \mathrm{C}$ in moist air.

\begin{tabular}{|l|c|c|l|}
\hline \multicolumn{3}{|c|}{ Alloy Composition a/o } & Phases Identified \\
\hline $\mathrm{Ni}$ & $\mathrm{Al}$ & $\mathrm{Be}$ & \\
\hline 50 & 50 & 0 & $\mathrm{NiAl}+\alpha-\mathrm{Al}_{2} \mathrm{O}_{3}$ \\
\hline 50 & 49 & 1 & $\mathrm{NiAl}+\mathrm{BeAl}_{2} \mathrm{O}_{4}$ \\
\hline 50 & 48 & 2 & $\mathrm{NiAl}+\mathrm{BeAl}_{2} \mathrm{O}_{4}$ \\
\hline 50 & 45 & 5 & $\mathrm{NiAl}+\mathrm{BeAl}_{2} \mathrm{O}_{4}+\mathrm{X}$ \\
\hline 50 & 42.5 & 7.5 & $\mathrm{NiAl}+\mathrm{BeAl}_{2} \mathrm{O}_{4}+\mathrm{X}$ \\
\hline 50 & 40 & 10 & $\mathrm{NiAl}+\mathrm{X}$ \\
\hline
\end{tabular}

\section{$\underline{T i-A l}$ and Ti-Al-Cr Based Alloys}

The oxidation behavior of the Be modified TiAl and $\mathrm{Ti}-\mathrm{Al}-\mathrm{Cr}$ alloys was screened in dry air at $800^{\circ} \mathrm{C}$ or $1000^{\circ} \mathrm{C}$. Only the alloys which exhibited adherent, protective scales in dry air were evaluated in moist air at $1000^{\circ} \mathrm{CThe}$ results of XRD studies of the oxidized alloys are shown in Table II.

Table II- Phases identified by XRD on Be modified Ti-Al and Ti-Al-Cr based alloys.

\begin{tabular}{|c|c|c|c|c|}
\hline $\begin{array}{c}\text { Oxidation } \\
\text { Conditions }\end{array}$ & \multicolumn{4}{|c|}{ Alloys (a/o) } \\
\hline & Ti-50Al-12.5Be & $\begin{array}{c}\text { Ti-45Al-7.5Cr- } \\
7.5 \mathrm{Be}\end{array}$ & $\begin{array}{c}\mathrm{Ti}-45 \mathrm{Al}-15 \mathrm{Cr}- \\
5 \mathrm{Be}\end{array}$ & $\begin{array}{c}\text { Ti-47.5Al- } \\
10 \mathrm{Cr}-5 \mathrm{Be}\end{array}$ \\
\hline Dry Air $800^{\circ} \mathrm{C}$ & TiAl, other & $\mathrm{TiAl}, \mathrm{BeAl}_{2} \mathrm{O}_{4}$ & $\begin{array}{c}\text { TiAl, Laves, } \\
\mathrm{BeAl}_{2} \mathrm{O}_{4}\end{array}$ & $\begin{array}{c}\text { TiAl, Laves, } \\
\text { BeAl } \mathrm{O}_{4}\end{array}$ \\
\hline $\begin{array}{c}\text { Dry Air, } \\
1000^{\circ} \mathrm{C}\end{array}$ & $\begin{array}{c}\mathrm{SPALLED} \\
\mathrm{TiAl}, \mathrm{TiO}_{2}, \\
\mathrm{Al}_{2} \mathrm{O}_{3}, \mathrm{BeAl}_{2} \mathrm{O}_{4}\end{array}$ & $\mathrm{TiAl}, \mathrm{BeAl}_{2} \mathrm{O}_{4}$ & $\begin{array}{c}\text { TiAl, Laves, } \\
\mathrm{BeAl}_{2} \mathrm{O}_{4}, \text { other }\end{array}$ & $\begin{array}{c}\text { TiAl, Laves, } \\
\mathrm{BeAl} \mathrm{O}_{4}, \text { other }\end{array}$ \\
\hline $\begin{array}{c}\text { Most Air, } \\
1000^{\circ} \mathrm{C}\end{array}$ & Not Run & SPALLED & $\mathrm{BeAl}_{2} \mathrm{O}_{4}$, other & $\mathrm{BeAl}_{2} \mathrm{O}_{4}^{\prime}$, other \\
\hline
\end{tabular}


The Ti-Al-Cr-Be alloys all had $\gamma$-TiAl as the major phase. Alloys with $10-15 \mathrm{a} / \mathrm{o}$ $\mathrm{Cr}$ also contained significant quantities of the hexagonal $\mathrm{C} 14$ Laves phase, $\mathrm{Ti}(\mathrm{Cr}, \mathrm{Al})_{2}$. It has yet to be determined whether the Be segregates preferentially to the $\gamma$ or Laves phases.

The poor oxidation behavior of Ti-50Al-12.5Be suggests that an oxidationresistant $\gamma+\mathrm{Laves} \mathrm{TiAl}+\mathrm{Ti}(\mathrm{Be}, \mathrm{Al})_{2}$ analogue to the alumina-forming $\gamma+\mathrm{Laves} \mathrm{Ti}-\mathrm{Al}-$ $\mathrm{Cr}$ alloys may not exist (Fig. 1). However, when added to the borderline aluminaforming Ti-Al-Cr alloys, Be resulted in the formation of the $\mathrm{BeAl}_{2} \mathrm{O}_{4}$ spinel phase (Fig. $3)$, which was shown to be protective when formed on $\mathrm{Ni}(\mathrm{Al}, \mathrm{Be})$ alloys (11). Therefore, it appears that $\mathrm{Be}$ additions to the borderline alumina-forming $\mathrm{Ti}-\mathrm{Al}-\mathrm{Cr}$ alloys show promise for improved oxidation resistance.

A detrimental effect of moisture in air was observed at $1000^{\circ} \mathrm{C}$, but only for the Ti-45Al-7.5Cr-7.5Be alloy. Previous work showed that water vapor detrimentally effects the oxidation resistance of $\mathrm{Cr}$ modified single-phase $\gamma$ alloys at $1000^{\circ} \mathrm{C}$ in air, but not two-phase $\gamma+$ Laves Ti-Al-Cr alloys (18). The XRD analysis indicated that Ti-45Al$7.5 \mathrm{Cr}-7.5 \mathrm{Be}$ is primarily single-phase $\gamma$. Therefore, the poor oxidation resistance of Ti$45 \mathrm{Al}-7.5 \mathrm{Cr}-7.5 \mathrm{Be}$ in moist air is consistent with this previous work.

Finally, it should be noted that although mechanical property measurements were not made, extensive microcracking was observed in the Be containing alloys. Therefore, it would appear that no improvement (in fact, degradation) in mechanical properties was imparted by alloying $\mathrm{Ti}-\mathrm{Al}-\mathrm{Cr}$ alloys with $\mathrm{Be}$ at the levels investigated.

\section{SUMMARY}

The effects of $\mathrm{Be}$ additions on the oxidation behavior of $\beta-\mathrm{NiAl}$ in moist air at $1000^{\circ} \mathrm{C}$ and borderline alumina-forming $\gamma+$ Laves Ti-Al-Cr based alloys at $800^{\circ} \mathrm{C}$ and $1000^{\circ} \mathrm{C}$ in dry and moist air were investigated. The preliminary results of this study suggest:

1) Additions of only $1 \mathrm{a} / \mathrm{o} \mathrm{Be}$ to $\beta$-NiAl and borderline alumina-forming $\gamma+$ Laves Ti-Ál$\mathrm{Cr}$ alloys result in the formation of an apparently protective $\mathrm{BeAl}_{2} \mathrm{O}_{4}$ spinel phase.

2) The presence of moisture in air at $1000^{\circ} \mathrm{C}$ showed no detrimental effect on the oxidation resistance of $\mathrm{Be}$ modified $\beta-\mathrm{NiAl}$ alloys.

3) The presence of moisture in air at $1000^{\circ} \mathrm{C}$ detrimentally affected the oxidation resistance of a primarily single-phase $\mathrm{Cr}$ and $\mathrm{Be}$ modified $\gamma$ alloy, but had no detrimental effect on the oxidation of two-phase $\gamma+$ Laves Ti-Al-Cr Be alloys. 
4) There appears to be no oxidation-resistant $\mathrm{TiAl}+\mathrm{Ti}(\mathrm{Be}, \mathrm{Al})_{2}$ analogue to the aluminaforming $\gamma+$ Laves $\mathrm{Ti}-\mathrm{Al}-\mathrm{Cr}$ alloys.

5) The addition of Be to borderline alumina-forming $\gamma+$ Laves Ti-Al-Cr alloys appears to degrade crack resistance and room temperature mechanical properties. .

\section{REFERENCES}

1. J. L. Smialek, Metallurgical Transactions A, 9A, pp. 309-320, (1978)

2. G.C. Rybicki and J.L. Smialek, Oxidation of Metals, 31 pp275-304, (1989).

3. J. Doychak, J.L. Smialek, and T.E. Mitchell, Metallurgical Transactions A, 20A, 499$518,(1989)$.

4. H.J. Grabke, M. Steinhorst, M. Brumm, and D. Wiemer, Oxidation of Metals, $\underline{35}$ pp199-222, (1991).

5. D.B. Miracle, Acta Metallurgica et Materialia, 41, pp649-682, (1992)

6. R.D. Noebe, R.R. Bowman, and M.V. Nathal, International Materials Reviews, $\underline{38}$, pp193-232, (1993).

7. J.D. Cotton, R.D. Noebe, and M.J. Kaufman, in "Structural Intermetallics", R.Darolia et al. eds., pp 513-522, TMS, Warrendale, Pa., (1993).

8. E.P. George and C.T. Liu, Journal of Materials Research, $\underline{5}$, pp 754-762, (1990).

9. R. Jayaram and M.K. Miller, Acta Metallurgica et Materialia, 42, pp1561-1572, (1994).

10. J.S. Lee and T.G. Nieh, in "Oxidation of High Temperature Intermetallics", T. Grobstein and J. Doychak, eds., pp271-279. TMS, Warrendale, Pa., (1989).

11. R. J. Hanrahan, D. P. Butt, D. J. Thoma, T. N. Taylor, and C. J. Maggiore, proceedings of the $13^{\text {th }}$ International Corrosion Congress, Melbourne, Australia, Nov 2529, 1996, 305/1-6. (1996).

12. D.W. Aylmore, S.J. Gregg, and W.B. Jepson, J. Nuc. Mat. 3/2, 190-200, (1961).

13. F. Ya. Galakhov, Izv. Akad. Nauk SSR Otdel. Khim. 1062-7 (1957), English Translation.

14 R.L. McCarron, J.C. Schaeffer, G.H. Meier, D. Berztiss, R.A. Perkins, and J. Cullinan in Titanium 1992, F.H. Froes and I. Caplan, eds., TMS, p. 1971 (1993).

15. M.P. Brady, W.J. Brindley, J.L. Smialek, and I.E. Locci, JOM, 48, 11 p. 46 (1996).

16. R.A. Perkins and G.H. Meier, in Proceedings of the Industry-University Advanced Materials Conference II, Smith, F. ed., Advanced Materials Institute, p. 92 (1989).

17. M.P. Brady, J.L. Smialek, J.W. Smith, and D.L. Humphrey, Acta Materialia, Vol. 45, No. 6, pp. 2357-2369 (1997).

18. M.P. Brady, J.L. Smialek, D.L. Humphrey, and J.W. Smith, Acta Materialia, Vol. 45, No. 6, pp. 2371-2382 (1997). 


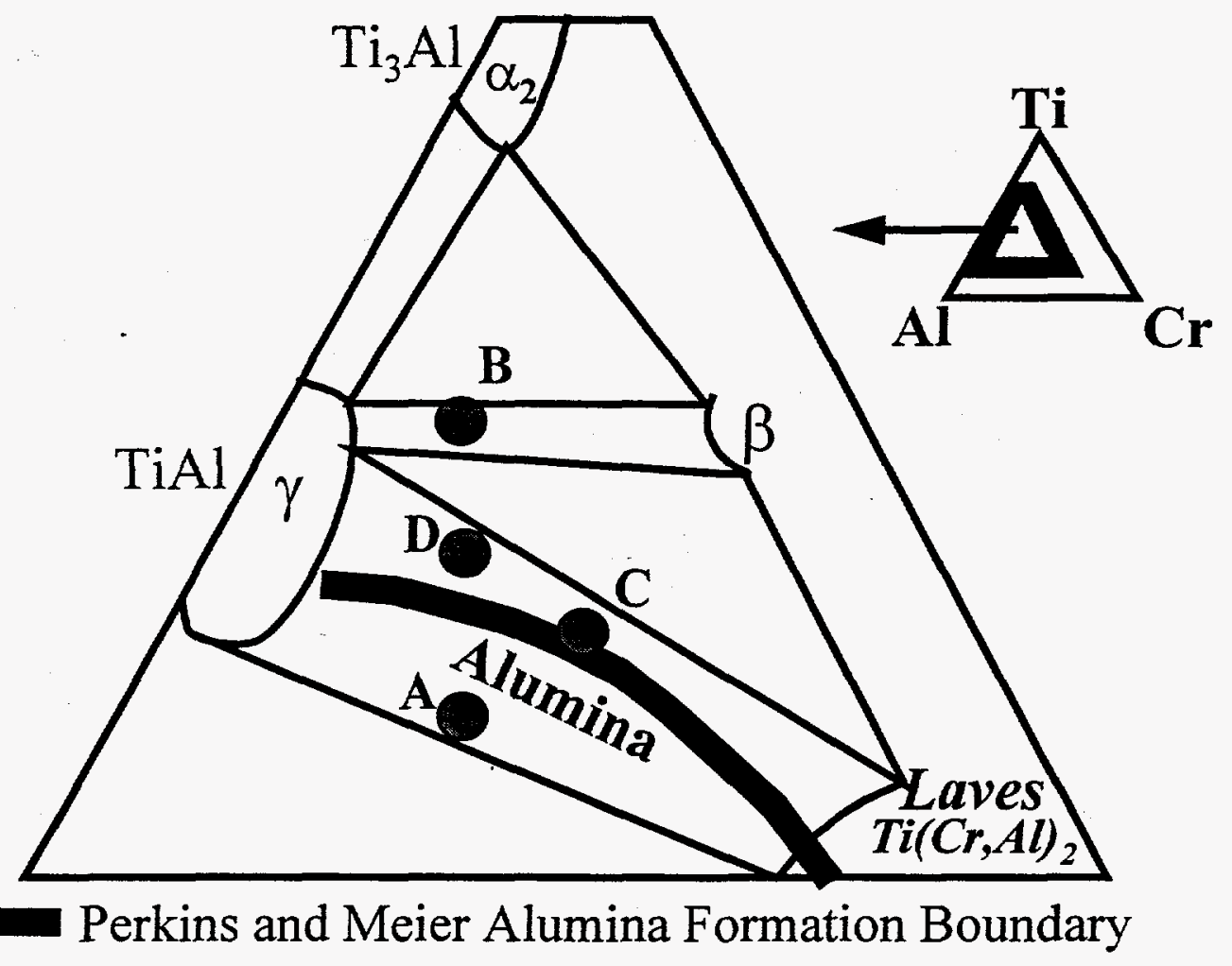
A: Ti-50Al-12.5Be
$\mathrm{B}$ : $\mathrm{Ti}-45 \mathrm{Al}-7.5 \mathrm{Cr}-7.5 \mathrm{Be}$
C: Ti-45Al-15Cr-5Be
D: $\mathrm{Ti}-47.5 \mathrm{Al}-10 \mathrm{Cr}-5 \mathrm{Be}$

Figure 1- Schematic $800-1000^{\circ} \mathrm{C}$ Ti-Al-Cr phase diagram (15) showing alloys selected for study. Note that the Ti-Al-Cr-Be alloys are schematically plotted based on the $\mathrm{Al}$ and $\mathrm{Cr}$ contents only, and that Ti-50Al-12.5Be is plotted as Ti-50Al-12.5Cr. 

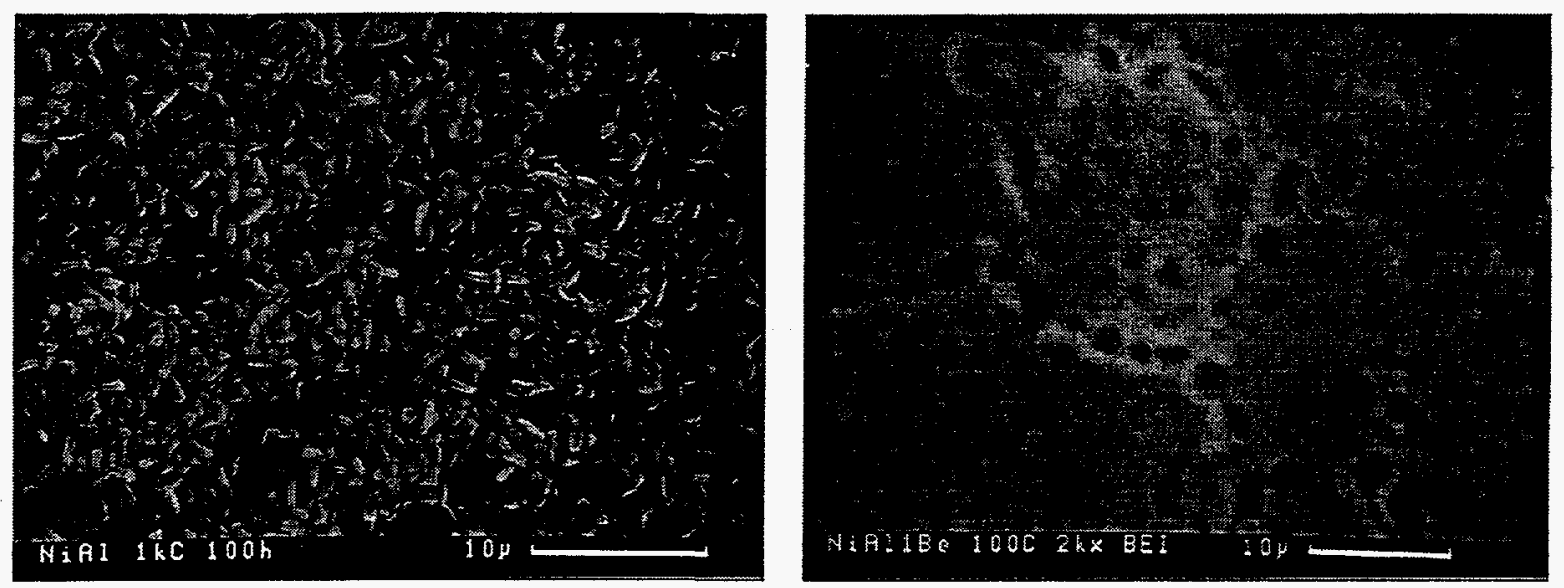

Figure 2: SEM (backscatter mode) surface micrographs of binary $\beta$-NiAl (left) and Ni$49 \mathrm{Al}-1 \mathrm{Be}$ (right) after exposure for $100 \mathrm{~h}$ at $1000^{\circ} \mathrm{C}$ in air saturated with moisture at $20^{\circ} \mathrm{C}$.

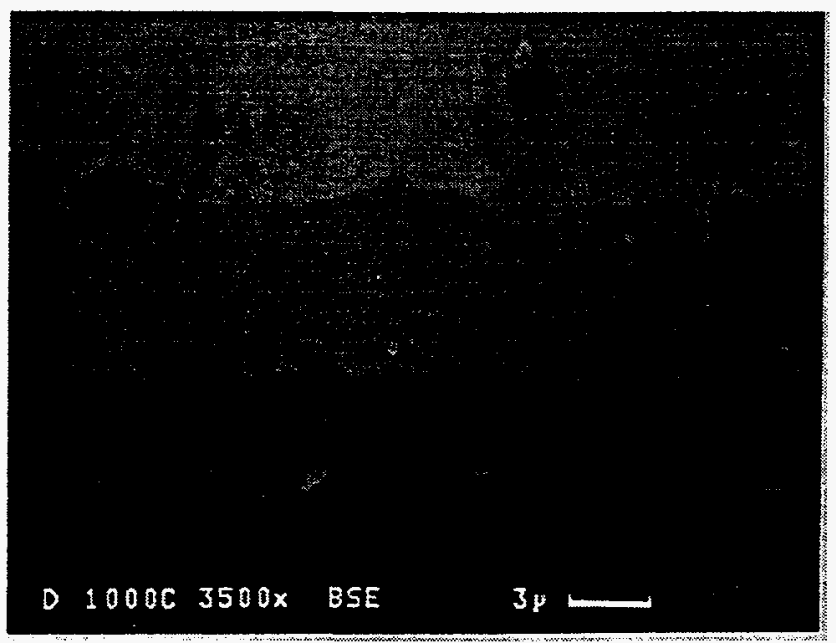

Figure 3: SEM (back-scatter mode) cross section of alloy Ti-47.5Al-10 Cr-5Be showing the scale (at bottom) consisting of mostly $\mathrm{BeAl}_{2} \mathrm{O}_{4}$. $\mathrm{An} \mathrm{Al}$ (and possibly $\mathrm{Be}$ ) depleted, $\mathrm{Cr}$ rich region is visible behind the scale. 